\title{
PROPAGATION OF RADIO WAVES ALONG THE EARTH
}

$\mathrm{T}$

HE mode of propagation of electrie waves along the surface of the earth has been investigated theoretically since the earliest days of practical radio communication, and a paper by A. Sommerfeld published in 1909 has since become a classical treatise on this subject. After a period during which attention was mainly confined to the study of wave propagation through the ionosphere, the inception of broadcasting and the practical application of ultra-short waves have caused renowed interest in the problem of propagation along the ground.

Two papers having a direct bearing on this subject have recently been issued by the Institution of Electrical Engineers, and would, in normal circumstances, have been read before a meeting of the Wireless Section on January 3 . The first, by Dr. J. S. McPetrie and Miss A. C. Stickland, is entitled "Reflection Curves and Propagation Characteristies of Radio Waves along the Earth's Surface" ; it deals with the evaluation of the reflection coefficient of the earth's surface, and then with the application of this knowledge to the study of propagation along the earth. A collection of curves given in this and an earlier paper enables the refiection coefficient for radio waves of any frequency and state of polarization to be determined for any angle of incidence and for various values of electrical constants of the earth.

It is pointed out that the ray theory, on which the reflection from a surface is assumed to be equal to the radiation from an image of the transmitting aerial, is not applicable at grazing incidence unless the heights of the transmitting and receiving aerials are comparable with the wave-length. From an analysis given by K. A. Norton, however, it is deduced that, when the ray theory does not apply, the field at the receiver is equal in most practical cases to the vector addition of two fields; the first is the field given by the simple ray theory while the second, which is independent of the heights of transmitter and receiver, corresponds to the surface wave first postulated by Sommerfeld for vertically polarized waves. The ratio of the magnitudes of the surface wave to the image fields is much less for horizontally than for vertically polarized waves, so that the ray theory is applicable over a wider range of angle of incidence in the former case. As the surface wave is independent of height, this results in the well-known experimental fact that the vertical field from a low transmitting aerial increases in magnitude with height at a much smaller rate than the horizontally polarized field.

The second paper, by Dr. J. S. McPetrie and Mr. $J$. A. Saxton, describes the results of an experimental investigation of the characteristics within optical range of the propagation overland of radio waves of length 2 and 3 metres. Measurements of the field strength received at various distances from the transmitter confirm the theoretical deduction that, provided the heights of both transmitting and receiving aerials are comparable with the wavelength, the propagation at grazing incidence is the same for both horizontally and vertically polarized waves. In either case, the field strength is proportional to the product of the heights of the transmitter and receiver, and inversely proportional to the square of the distance between them. It was found that, within the optical range of the transmitter, the propagation characteristics corresponded to the condition of a plane rather than a spherical earth, although the varying contours of the path of transmission produced a marked effect on the received field strength. Over a town area, the ratio of the measured to the theoretical field strength was less on a wave-length of 2 metres than on 3 metres.

\section{CAVE FAUNAS}

\begin{abstract}
$\mathrm{T}$ HE specialized cave faunas of the world have been investigated extensively during the last fifty years, and to this prolific literature is now added the results of exploration in the numerous caves of Belgium. Dr. R. Leruth contributes "La Biologie du Domaine Souterrain et la Faune Cavernicole de la Belgique" (Mém. 87. Musée Royal d'histoire naturelle de Belgique, 1939), and in the same series, Mém. 88 by Dr. C. R. Boettger is entitled "Die Subterrane Molluskenfauna Belgiens".

The vast grottoes near Han-sur-Lesse furnished much of the material, although forty-eight subterranean regions were explored. The collections were submitted to specialists for identification. A general section deals with the ecological and geological conditions affecting the Belgian cave faunas, and Dr. Leruth classifies the inhabitants as permanent, temporary or accidental cave-dwellers. The first are completely adapted to their mode of life, the second can live either within or without underground areas, and the third are ill-adapted to eave life and are
\end{abstract}

incapable of breeding there. There are also parasites and scavengers. The terrestrial fauna is poor in species, but the aquatic fauna is relatively rich. Of approximately six hundred species, one genus and sixteen species are new. Bats, mice and rats are the chief mammals, while badgers and foxes penetrate into the smaller caverns. Neither fishes nor amphibia are recorded. Among invertebrates, flatworms, roundworms and ringed worms, arthropods of all kinds and in large numbers, and some molluses were found.

Dr. Boettger describes the collections of Dr. Leruth and Prof. Séverin. Pisidium is the only lamellibranch genus. Among prosobranchs there are several members of the Hydrobiidæ. Pulmonates are common, especially as the faunas of crevices and underground water channels are included. A blind land snail, Caecilioides acicula, and the freshwater prosobranch, Avenionia bourguignati, are true cave forms, the latter being a French species recorded for the first time in Belgium. 